\title{
University Experiences and Satisfaction of Vietnamese University Students
}

\author{
Minh-Quang Duong, Ph.D \\ University of Social Sciences and Humanities \\ Vietnam National University Ho Chi Minh City \\ 10-12 Dinh Tien Hoang Street, District 1, Ho Chi Minh City, Vietnam \\ E-mail: mqduong.ussh@yahoo.com
}

Received: March 5, 2015 Accepted: August 26, 2015 Published: November 1, 2015

doi:10.5296/jse.v5i4.8344 URL: http://dx.doi.org/10.5296/jse.v5i4.8344

\begin{abstract}
Student satisfaction is an important part of the effort to market higher education successfully and learning programs, and an important factor in measuring the quality of learning approach. This study explored the student satisfaction in Vietnamese higher education, and how student satisfaction was affected by personal and university experience variables. A quantitative research method was used in the study; out of the 618 third-year students of 24 departments and faculties at in the University of Social Sciences and Humanities - Vietnam National University Ho Chi Minh City responded to the study and were study participants. The findings of this study show that students were moderately satisfied with their environment on campus. The study also shows that of university experiences had significant positive effects and personal variable had significant negative effects on student satisfaction.
\end{abstract}

Keywords: student satisfaction, personal variables, university experiences, higher education, Vietnam 


\section{Introduction}

Cheng and Tam (1997) found that there are seven models for quality education, namely 1) satisfaction, 2) goal, 3) absence of problems, 4) resource-input, 5) organizational learning, 6) legitimacy, and 7) process. The satisfaction model is a good option from which strategies for quality education can be adopted and developed. Education institutions consider student satisfaction to be one of the major elements in determining the quality of open programs in today's markets (Kuo, Walker, Belland, \& Schroder, 2013). Especially universities are developing new strategies to measure quality with reference to student satisfaction (Mark, 2013). The demands and needs of students are critical for higher educational institutions if they want to be competitive (Khosravi, Poushaneh, Roozegar, \& Sohrabifard, 2013). According to Leckey and Neill (2001), any student satisfaction questionnaire should be open to access with evaluation and possible attitude of leadership regarding the steps to improve the current situation. Student satisfaction is described proportional to the students' perceived value concerning their educational institutions and experiences (Doris \& Oksana, 2009).

According to Elliott and Shin (2002), student satisfaction in higher education is defined as "the favorability of a student's subjective evaluation of the various outcomes and experiences associated with education". Student satisfaction is being shaped continually by various outcomes and their experiences in campus life. The studies of the factors influencing satisfaction of higher education students can provide relevant information about how students are thinking and what the most important areas to consider are, when it comes to student satisfaction (Pop, Bacila, Moisescu, \& Tirca, 2008). Sinclaire (2011) showed that there are three reasons for interest in student satisfaction: 1) the most important key to continuing learning, 2) positively related to retention and a decision to take one or more additional courses, and 3) represent a public relations asset for higher education institutions.

Student satisfaction is considered an important factor in measuring the quality of learning approach and a key factor in the success of learning programs. Student satisfaction is an important part of the effort to market higher education successfully (Hermans, Haytko, \& Mott-Stenerson, 2009). Student satisfaction in higher education approaches may be a tool for building a bridge between more traditional and academic views on how to improve higher education institutions, and more market-orientated perspectives (Wiers-Jenssen, Stensaker, \& Grogaard, 2002). The studies of Arambewela and Hall (2009) and Usman (2010) showed that due to an increasingly competitive, dynamic, and challenged educational environment, universities are becoming more aware of the importance of student satisfaction. Research of student satisfaction in higher education, therefore, not only enables universities to re-engineer their organizations to adapt to student needs, but also allows them to develop a system for continuously monitoring how effectively they meet or exceed student needs (O'Neill, 2003). Students' needs and expectations allow educational institutions to attract, and retain quality students, and improve the quality of their programs (Elliott \& Shin, 2002). Sandhu and Kapoor (2014) recognized that student satisfaction is important and needs to be continuously assessed to assure quality of education experiences for students. Student satisfaction is important because it influences the student's level of motivation (Chute, Thompson, \& 
Hancock, 1999), which is an important psychological factor in student success (American Psychological Association, 1997).

Student satisfaction is a complex concept consisting of several dimensions (Marzo-Navarro, Iglesias, \& Torres, 2005; Richardson, 2005). Student satisfaction in higher education is influenced by a number of variables. Several past studies show that there were related factors influencing student satisfaction namely the quality of courses (Arif, Ilyas, \& Hameed, 2013; Wilkins \& Balakrishnan, 2013), effectiveness of instructional process (Elliot \& Healy, 2001; Helgesen \& Nesset, 2007), course organization (Navarro, Iglesias, \& Torres, 2005), interaction with students (O'Driscoll, 2012), the focus on student's needs (Elliot \& Healy, 2001) and campus climate (Sojkin, Bartkowiak, \& Skuza, 2012; Sultan \& Wong, 2012). According to DiBiase (2004) and Garcia-Aracil (2009), student satisfaction is a complex yet poorly articulated notion.

This study explored the student satisfaction in Vietnamese higher education, and how student satisfaction was affected by personal and university experience variables. The findings of this study will provide instructors, administrators, educators, and other concerned entities with data regarding course satisfaction of university students toward environment campus approach. The study is designed to answer two questions: 1) What is the general level of student satisfaction in Vietnamese university? and 2) How is student satisfaction affected by personal and university experience variables?

\section{Research Method}

\subsection{Sample}

The survey instrument was distributed to 700 students of 24 departments and faculties at the University of Social Sciences and Humanities - Vietnam National University Ho Chi Minh City (USSH-VNUHCM), of which 618 questionnaires were returned, for an $88.3 \%$ return rate, which exceeds the $30 \%$ response rate most researchers require for analysis (Dillman, 2000; Malaney, 2002). The sample of this study was drawn from 618 respondents who completed the survey instrument. Participants in this study were third-year full-time students who were studying on campus. According to Huang and Chang (2004), third-year students are considered the best population for observing student involvement and development at the university.

\subsection{Dependent and Independent Variables}

A dependent variable is a criterion or variable that is to be predicted or explained (Zikmund, 2003). Student satisfaction is the dependent variable in the study. This study used three dimensions to measure student satisfaction namely campus landscape, conservation campus, and parking on campus. The dimensions of the student satisfaction were measured with assessments using a four-point Likert scale ranging from $1=$ "very dissatisfied" to 4 = "very satisfied". Factor analysis of the constructed dependent variable yielded adequate validity, showing factor loading values of the three items $(0.69-0.83)$ greater than the threshold value of 0.5 (Hair, Tatham, Anderson, \& Black, 2009). Internal consistency analysis revealed a Cronbach's coefficient (0.70) higher than the threshold value of 0.6 (Nunnally, 1978), 
indicating a satisfactory reliability. Total variance explained was $61.32 \%$, meeting the requirement of constructed variable for social science research (Hair et al., 2009).

An independent variable is a variable that is expected to influence the dependent variable (Zikmund, 2003). In the study, personal and university experience variables are the independent variables. For personal variables, they include gender, age, family income, and discipline. University experiences include teaching approach (such as one-way instruction, Interaction teacher vs. student, practice or experiment, and topic research), curriculum engagement (namely memory emphasis, integration emphasis, evaluation emphasis, and application emphasis), and co-curriculum involvement (including student government, sport group, social service, and art culture group)

\subsection{Data Analysis Methods}

Data collection for this study was gathered from survey questionnaires administered to 618 students in the USSH-VNUHCM. This study employs statistical methods of descriptive analyses, and regression to analyze the data. Descriptive analysis is conducted to understand the general level of student satisfaction in Vietnamese higher education. To study the personal and university experience variables which significantly affect student satisfaction, multiple regressions analysis was used for this study. After checking the precision of data entry and making codes for data analysis with the statistical analysis program, SPSS version 13.0, the following statistics were used.

\section{Results and Discussion}

\subsection{Participants of the study}

The findings of Table 1 show that out of the 618 third-year students in the USSH-VNUHCM, $51.6 \%$ were male and $48.4 \%$ of female students. The respondents consisted of $74.3 \%$ who were 21 years old. Regarding ethnic groups, 93.2\% of students were majority of ethnic, remaining $6.8 \%$ were ethnic minority. In terms of their father's education, $34.5 \%$ of students had senior high school, and $24.8 \%$ had attained junior high school. Similarly, the mother's education, also focused on senior high school (30.4\%), and junior high school (26.1\%). For family income, $22.5 \%$ of students had under USD 1,000 and 32.8\% were over USD 3,100. Regarding students' discipline, 90.6\% were fields of social sciences, and remaining 9.4\% faculty were fields of humanities.

\subsection{The general level of student satisfaction at the USSH-VNUHCM}

The survey used four-point Likert scales with responses ranging from 1 = very dissatisfied to $4=$ very satisfied. In terms of Table 2 the findings indicated that students in the USSH-VNUHCM were moderately satisfied with their campus environment $(M=2.78, S D=$ $0.56)$. 
Table 1. The Results of Means $(M)$ and Standard Deviations $(S D)$ of Student Satisfaction Level in the USSH-VNUHCM

\begin{tabular}{lccc}
\hline Student satisfaction dimensions & Scores range & $M$ & $S D$ \\
\hline Average of three dimensions & & 2.78 & 0.56 \\
1. Campus landscape & $1-4$ & 2.89 & 0.71 \\
2. Conservation campus & & 2.87 & 0.66 \\
3. Parking on campus & & 2.59 & 0.80 \\
\hline
\end{tabular}

In this study, the results of descriptive analysis showed that the average of the three dimensions of student satisfaction is $69.5 \%(2.78 / 4)$ indicating a moderate level of job satisfaction for students in USSH-VNUHCM by comparing the scale of 4 . This finding for Vietnam is supported by studies in Germany (Gruber, Fuß, Voss \& Glaeser-Zikuda, 2010), the Czech Republic (Enache, 2011). These studies used a five-point Likert scale with responses ranging from $1=$ very dissatisfied to $5=$ very satisfied to measure the level of student satisfaction with the university. These studies showed that the average level of student satisfaction in Germany was 50\% (2.5/5), in the Czech Republic, it was 69.8\% (3.49/5). The study of student satisfaction in Bangladesh universities, Mazumder (2013) found that students of private universities are least satisfied with weekend activities, whereas students of public university are least satisfied with teachers' understanding of unique life situations and unbiased treatment factors.

Although each study used different methods, approaches and instruments to measure satisfaction for students in higher education, this study, like the other cited above, indicated that Vietnamese students were moderately satisfied with their campus environment. This means that the level of student satisfaction in the USSH-VNUHCM is comparable to those in both developing and developed countries. However, there is still much room for university administrators to improve the level of satisfaction of students in the USSH-VNUHCM.

\subsection{Regression between university experiences and student satisfaction in the USSH-VNUHCM}

Regression model proposed by this study explained $4.3 \%\left(\mathrm{R}^{2}=0.043\right)$ of student satisfaction in the USSH-VNUHCM. These models present coefficients of $\beta$ values, with $\beta>0$ indicating a positive effect and $\beta<0$ indicating a negative effect on student satisfaction. However, the different regression models had different explanations for student satisfaction across personal and university experience variables. Table 2 displays three models of multiple regression statistics which analyzed the effect across personal and university experience variables on student satisfaction in the USSH-VNUHCM. Models 1 through 4 presented the separate effect of these factors on student satisfaction, and Model 5 reported the combined effects. 
Table 2. Regression Analysis Results between Student Satisfaction and Personal and University Experience Variables

\section{Model $1 \quad$ Model 2 Model $3 \quad$ Model $4 \quad$ Model 5}

\section{Personal variables}

Gender

Age

$-.080$

Family income

$-.045$

Discipline

.062

\section{University experience variables}

\section{Teaching approach}

One-way instruction

Interaction teacher vs. student

Practice or experiment

Topic research

\section{Curriculum engagement}

Memory emphasis

$$
-.053
$$

Integration emphasis

Evaluation emphasis

Application emphasis

\section{Co-curriculum involvement}

Student government

Sport group

Social service

Art culture group

\begin{tabular}{llllll}
\hline Adjusted $R^{2}$ & .005 & .015 & .015 & .013 & .043 \\
\hline Note. ${ }^{*} p<.05, * * p<.01$ & & & &
\end{tabular}

As shown in Table 2, Model 1 suggested that personal variables as a whole did not have significant effects on student satisfaction in the USSH-VNUHCM. A previous study of Outcomes Working Group (OWG) (2003) recognized that a significant difference has been found between student satisfaction and personal variables. The finding of OWG showed that females and older students tended to report somewhat higher levels; unfortunately, there is yet no empirical research done about the relationship between student satisfaction and family income, discipline.

Model 2 showed that two items of teaching approach, namely practice or experiment $(\beta=$ $0.133, p<0.01)$, and topic research $(\beta=-0.095, p<0.05)$ had significant effect on student satisfaction. This finding was supported by the research of OWG (2003); teaching consistently exerted the most influence on satisfaction ratings $(r=.4529)$. However, topic research had a significant negative effect on student satisfaction. In the process of building 
and development topic research, hence, instructors of USSH-VNUHCM may want to avoid a teaching approach of topic research. Model 3 recognized that only integration emphasis of curriculum engagement generally yielded significant effects on student satisfaction $(\beta=0.119$, $p<0.01$ ). The research of OWG (2003) reported that there is a strong relationship between curriculum engagement and student satisfaction $(r=.4814)$.

Model 4 showed a significant effect of co-curriculum involvement on student satisfaction; however, the only social service of co-curriculum involvement had consistently significant effects on student satisfaction in the USSH-VNUHCM. Unfortunately, there is yet no empirical research done about the relationship between student satisfaction and co-curriculum involvement in Vietnam or even in other parts of the world. The results of this study thus cannot be compared to results of others. Further research about the relationship between student satisfaction and co-curriculum involvement will contribute to fill in the literature gap. Model 5 showed that collectively, one-way instruction $(\beta=0.032, p<0.05)$ and practice or experiment $(\beta=0.043, p<0.05)$ of teaching approach, integration emphasis $(\beta=0.120, p<$ $0.01)$ of curriculum engagement, and social service $(\beta=0.097, p<0.05)$ of co-curriculum involvement persistently exhibited significant positive effects on student satisfaction. Only age $(\beta=-0.083, p<0.05)$ among the personal variables showed a negative correlation with student satisfaction in the USSH-VNUHCM.

\section{Conclusion}

This study explored the student satisfaction in Vietnamese higher education, and how student satisfaction was affected by personal and university experience variables. The empirical results of the study revealed that students were moderately satisfied with their campus environment. Further, teaching approach, curriculum engagement, and co-curriculum involvement of university experiences correlated positively with student satisfaction; however, students' age correlated negatively with student satisfaction in the USSH-VNUHCM.

Student satisfaction has been considered an important factor in measuring the quality of learning approach, a key factor in the success of learning programs and a tool for building a bridge between more traditional and academic views on how to improve higher education institutions. This study has measured student satisfaction with campus environment (including campus landscape, conservation campus, and parking on campus) and investigated personal factors (such as gender, age, family income and discipline) and university experiences (namely teaching approach, curriculum engagement, and co-curriculum involvement) affecting student satisfaction in the USSH-VNUHCM.

The present study has some limitations. The primary limitation is that the study only sampled USSH-VNUHCM third-year students, hence, the results and implications should be applied with caution to students from different levels of Vietnamese higher education institutes. Further research should collect student samples from various higher education levels and disciplines to accumulate rich empirical information of Vietnamese university students. It is hoped that the barrier to the student satisfaction in the USSH-VNUHCM found in this study may help administrators and Vietnamese higher education institutes to built and develop a learning environment and campus climate that would allow higher levels of student 
satisfaction and contribute to filling the gap in the literature regarding Vietnam and other countries.

\section{References}

American Psychological Association. (1997). Learner-centered psychological principles: A framework for school redesign and reform. Washington, DC.

Arambewela, R., \& Hall, J. (2009). An empirical model of international student satisfaction. Asian Pacific Journal of Marketing and Logistics, 21(4), 555-569. http://dx.doi.org/10.1108/13555850910997599

Arif, S., Ilyas, M., \& Hameed, A. (2013). Student satisfaction and impact of leadership in private universities. The TQM Journal, 25(4), 399-416. http://dx.doi.org/10.1108/17542731311314881

Cheng, Y. C., \& Tam, W. M. (1997). Multi-models of quality in education. Quality Assurance in Education, 5(1), 22 - 31. http://dx.doi.org/10.1108/09684889710156558

Chute, A. G., Thompson, M. M., \& Hancock, B. W. (1999). The McGraw-Hill handbook of distance learning. New York: McGraw-Hill.

DiBiase, D. (2004). The impact of increasing enrolment on faculty workload and student satisfaction over time. Journal of Asynchronous Learning Networks, 8(2), 45-60.

Dillman, D. A. (2000). Mail and internet surveys: The tailored design method. New York: John Wiley and Son.

Doris U. B., \& Oksana, W. (2009). Factors influencing faculty satisfaction with online teaching and learning in higher education. Distance Education, 30(1), 103-116. http://dx.doi.org/10.1080/01587910902845949

Elliot, K. M., \& Healy, M. A. (2001). Key factors influencing students satisfaction related to recruitment and retention. Journal of Marketing for Higher Education, 10(4), 1-12. http://dx.doi.org/10.1300/J050v10n04_01

Elliott, K. M., \& Shin, D. (2002). Student satisfaction: An alternative approach to assessing this important concept. Journal of Higher Education Policy and Management, 24(2), 197-209. http://dx.doi.org/10.1080/1360080022000013518

Enache, I. C. (2011). Customer behaviour and student satisfaction. Bulletin of the Transilvania University of Braşov, 4(53), 41-46.

Garcia-Aracil, A. (2009). European graduates' level of satisfaction with higher education. Higher Education, 57, 1-21. http://dx.doi.org/10.1007/s10734-008-9121-9

Gruber, T., Fuß, S., Voss, R., \& Glaeser-Zikuda, M. (2010). Examining student satisfaction with higher education services using a new measurement tool. International Journal of Public Sector Management, 23(2), 105-123. http://dx.doi.org/10.1108/09513551011022474

Hair, J. F., Tatham, R.L., Anderson, R.E., Black, W. (2009). Multivariate data analysis (6 
ed.). Upper Saddle River, NJ: Prentice Hall

Helgesen, O, \& Nesset, E. (2007). What accounts for students' loyalty? Some field study evidence. International Journal of Public Sector Management, 21 (2), 126-143. http://dx.doi.org/10.1108/09513540710729926

Hermans, C. H., Haytko, D. L., \& Mott-Stenerson, B. (2009). Student satisfaction in Web-enhanced learning environments. Journal of Instructional Pedagogies, 1, 1-19.

Huang, Y., \& Chang, S. M. (2004). Academic and co-curricular involvement: Their relationship and the best combinations for student growth. Journal of College Student Development, 45(4), 391 - 406. http://dx.doi.org/10.1353/csd.2004.0049

Khosravi, A. A., Poushaneh, K., Roozegar, A., \& Sohrabifard, N. (2013). Determination of factors affecting student satisfaction if Islamic Azad University. Procedia Social and Behavioral Sciences, 84, 579-583 http://dx.doi.org/10.1016/j.sbspro.2013.06.607

Kuo, Y. C., Walker, A. E., Belland, B. R., \& Schroder, K. E. E. (2013). A predictive study of student satisfaction in onlie education programs. The International Review of Research in Open and Distance Learning, 14(1), 16-39.

Leckey, J., \& Neill, N. (2001). Quantifying Quality: the importance of student feedback. Quality in Higher Education, 7(1), 19-32. http://dx.doi.org/10.1080/13538320120045058

Malaney, G. D. (2002). You still need high response rates with web-based surveys. Student Affairs On-Line, 3(1). Retrieved from http://studentaffairs.com/ejournal/Winter_2002/rates.html

Mark, E. (2013). Student satisfaction and the customer focus in higher education. Journal of Higher Education Policy and Management, 35(1), 2-10. http://dx.doi.org/10.1080/1360080X.2012.727703

Marzo-Navarro, M. M., Iglesias, M. P., \& Torres, M. P. R., (2005). A new management element for universities: satisfaction with the offered courses. International Journal of Educational Management, 19(6), 505-526. http://dx.doi.org/10.1108/09513540510617454

Mazumder, S. H. (2013). Engineering Student Satisfaction in Private and Public Universities in Bangladesh. Presented at the Proceedings of the 2013 ASEE North-Central Section Conference. American Society for Engineering Education

Navarro, M. M., Iglesias M. P., \& Torres P. R. (2005). A New Management Element for Universities: Satisfaction with the Offered Courses. International Journal of Education Management, 19(6), 505-526. http://dx.doi.org/10.1108/09513540510617454

Nunnally, J. C. (1978). Psychometric theory. New York: McGraw-Hill.

O'Driscoll, F. (2012). What matters most: An exploratory multivariate study of satisfaction among first year hotel/hospitality management students. Quality Assurance in Education, 20(3), 237-258. http://dx.doi.org/10.1108/09684881211240303 
O'Neill, M. (2003). The influence of time on student perception of service quality: the need for longitudinal measures. Journal of Educational Administration, 41(3), 310-324. http://dx.doi.org/10.1108/09578230310474449

OWG (Outcomes Working Group) (2003). Understanding student satisfaction. Issue Paper, 3(1), 1-4. Retrieved from http://www.kpu.ca/sites/default/files/downloads/ Understanding_Student_Outcomes6359.pdf

Pop, M. D., Bacila, M. F., Moisescu, O. I., \& Tirca, A. M. (2008). The impact of educational experience on students' satisfaction in the Romanian higher education system. International Journal of Business Research, 8(3). Retrieved from http://www.freepatentsonline.com/article/International-Journal-Business-Research/ 190617005 .html

Richardson, J. T. E. (2005). Instruments for obtaining student feedback: A review of the literature. Assessment and Evaluation in Higher Education, 30(4), 387-415. http://dx.doi.org/10.1080/02602930500099193

Sandhu, D., \& Kapoor, A. (2014). Determinants of students' satisfaction towards hybrid distance learning. Indian Journal of Applied Research, 4(8), 127-128. http://dx.doi.org/10.15373/2249555X/August2014/36

Sinclaire, J. (2011). Student satisfaction with online learning: Lessons from organizational behavior. Research in Higher Education Journal, 11, 1-18.

Sojkin, B., Bartkowiak, P., \& Skuza, A. (2012). Determinants of higher education choices and student satisfaction: the case of Poland. High Education, 6(5), 565-581. http://dx.doi.org/10.1007/s10734-011-9459-2

Usman, A. (2010). The Impact of Service Quality on Students' Satisfaction in Higher Education Institutes of Punjab. Journal of Management Research, 2(2). http://dx.doi.org/10.5296/jmr.v2i2.418.

Wiers-Jenssen, J.; Stensaker, B., \& Grogaard, J. (2002). Student satisfaction: towards an empirical deconstruction of the concept. Quality in Higher Education, 8(2), 183-195. http://dx.doi.org/10.1080/1353832022000004377

Willkins, S., \& Balakrishnan M. S. (2013). Assesing student satisfaction in transnational higher education. International Journal of Educational Management, 27(2), 143-156. http://dx.doi.org/10.1108/09513541311297568

Zikmund, G. W. (2003). Exploring marketing research ( $8^{\text {th }}$ ed.). South-Western: Thomson. 